\title{
The Relationship Between Stress Levels, Sleep Quality, and Oral Health-related Quality of Life in Turkish University Students with Self-reported Bruxism
}

\section{Bruksizmli Türk Üniversite Öğrencilerinde Stres Düzeyleri, Uyku Kaliteleri ve Ağız Sağlığına Illișkin Yașam Kaliteleri Arasındaki Illișki}

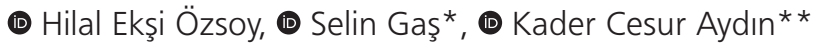 \\ Istanbul Galata University Faculty of Dentistry, Department of Prosthodontics, Istanbul, Turkey \\ *Beykent University Faculty of Medicine, Department of Oral and Maxillofacial Surgery, Istanbul, Turkey \\ **Istanbul Medipol University Faculty of Medicine, Department of Dentomaxillofacial Radiology, Istanbul, Turkey
}

\begin{abstract}
Objective: This study aimed to investigate the relationship between sleep quality, stress levels, and oral health-related quality of life of university students with self-reported sleep/awake bruxism in Turkey. Materials and Methods: Four anonymous questionnaires [Self-reported bruxism, perceived stress scale (PSS), Pittsburgh sleep quality index (PSQI), and oral health impact profile-14 [(OHIP-14)] were administered to 310 university student volunteers that were randomly selected from the various provinces of Turkey. The participants were required to respond independently to the questionnaires at home and were encouraged to contact the authors for further assistance if needed.

Results: Among the study participants, $56.8 \%$ were from the school of dentistry and $43.2 \%$ from other departments. Of all the participants, $29 \%$ had self-reported awake bruxism and $42.3 \%$ had self-reported sleep bruxism. A positive correlation was found between the PSS and OHIP-14 results (23.5\%) and between the PSQI and PSS (24.6\%) results in the students with self-reported awake bruxism $(p=0.235, p=0.246$; $\mathrm{p}<0.05$ ). A positive correlation was found between the PSS and OHIP-14 results (23.1\%) and between the PSQI and PSS (29.6\%) results in the students with self-reported sleep bruxism ( $p=0.231, p=0.296 ; p<0.05)$. Conclusion: Self-reported awake or sleep bruxism was found to be associated with higher stress levels and sleep disturbances and weaker oral health-related quality of life in university students.
\end{abstract}

Keywords: Bruxism, stress, sleep quality
Öz

Amaç: Bu çalışmanın amacı, Türkiye'de gece/gündüz bruksizmi olan üniversite öğrencilerinde uyku kalitesi, stres düzeyi ve ağız sağlığı ile ilgili yaşam kalitesi arasındaki ilişkiyi değerlendirmektir.

Gereç ve Yöntem: Türkiye'nin çeşitli illerinden rastgele seçilen 310 gönüllü üniversite öğrencisine dört farklı anket [self-reported bruksizm, algılanan stres ölçeği (PSS), Pittsburgh uyku kalitesi indeksi (PUKI) ve ağız sağlığı etki profili-14 (OHIP-14)] dağıtıldı. Katılımcılardan anketleri evde bağımsız olarak doldurmaları istendi ve gerekirse daha fazla yardım için araştırmacılarla iletişime geçmeleri istendi.

Bulgular: Katılımcıların \%56,8'i diş hekimliği fakültesinde, \%43,2'si diğer bölümlerde öğrenciydi. Öğrencilerin \%29'unda gündüz bruksizmi ve \%42,3'ünde gece bruksizmi vardı. Gündüz bruksizmi olan öğrencilerde PSS ile OHIP-14 arasında $(\% 23,5)$ ve PUKI ile PSS arasında $(\% 24,6)$ pozitif korelasyon bulundu $(p=0,235, p=0,246 ; p<0,05)$. Gece bruksizmi olan öğrencilerde PSS ile OHIP-14 arasında $(\% 23,1)$ ve PUKI ile PSS arasında $(\% 29,6)$ pozitif korelasyon tespit edildi $(p=0,231, p=0,296 ; p<0,05)$.

Sonuç: Çalışmamıza göre bruksizmli üniversite öğrencilerinde daha yüksek stres seviyeleri ve uyku bozuklukları ile birlikte ağız sağlığına ilişkin yaşam kalitesinin daha zayıf olduğu görülmektedir.

Anahtar Kelimeler: Bruksizm, stres, uyku kalitesi

\section{Introduction}

Bruxism is explained as the actions of clenching the teeth, supporting the jaws without real tooth contact and grinding the teeth while awake or asleep (1). American Academy of Sleep Medicine redefined sleep bruxism as "A movement disorder that occurs during sleep" in 2005, after the recognition of sleep bruxism as parasomnia (2). The etiology of sleep bruxism sophisticated, past studies are associated with environmental causes such as occlusal interventions and problematic anatomy, but current studies indicate that it is related to the central

Address for Correspondence/Yazışma Adresi: Assoc. Prof. Hilal Ekşi Özsoy, İstanbul Galata University Faculty of Dentistry, Department of Prosthodontics, İstanbul, Turkey Phone: +90 5348792303 E-mail: hilaleksi@gmail.com ORCID-ID: orcid.org/0000-0003-2061-9081

Received/Geliş Tarihi: 10.03.2021 Accepted/Kabul Tarihi: 07.10.2021

${ }^{\circ}$ Copyright 2022 by Turkish Sleep Medicine Society / Journal of Turkish Sleep Medicine published by Galenos Publishing House. 
nervous system (3). Risk factors associated with bruxism include habits such as smoking and alcohol use, disorders in neurotransmitters, stress and trauma (4). "Awake bruxism" is defined as the clenching of teeth and jaws when the individual is aware of the action of performance during the day, while awake (5). Daytime bruxism is defined as clenching of teeth and jaws rather than teeth grinding. The pathophysiology is not clearly known, but studies reveal that stress and anxiety are among serious risk factors $(5,6)$.

Although no direct relationship can be established, psychological factors are thought to have an important role in quality of life, affecting daily activities (7) and personal perception of oral health (8). Regarding the effect of bruxism on life quality of different populations, the 14-item oral health impact profile (OHIP-14) is the most widely used and validated measure (8-10). It evaluates health via a multi-faceted approach; from biological, psychological, social and cultural perspectives (10). The main method to understand an individuals' perception of diseases and the impact of the disease on the individual is detection of oral health related quality of life (OHRQoL). This detection enables healthcare professionals to focus on specific aspects of the illness and provide effective support to the patient in the course of their care $(11,12)$.

Bruxism is a sleep-related movement disorder, as increasing anxiety, stress-related repetitive arousal during sleep and poor sleep quality (13) are the main reasons. These factors alter wakefulness and the initiation and maintenance of sleep via chemical mediators that activate catecolamine release (14). Alteration of sleep patterns are reported to exacerbate pain in bruxism patients (15). Recent studies reveal that bruxism is significantly associated with chronic anxiety (16) and individuals reporting bruxism are twice as stressful as non-bruxism cases $(13,17)$.

There are studies on the relationship between bruxism and stress among university students (18-20). When stress studies on university students are evaluated in general, stress sources include academic and personal reasons, as well as the environmental and economic conditions. One of the signs of stress is the grinding and clenching of the teeth that occurs without a functional requirement (18-20).

It is important to investigate information on parafunctional habits and psychological states of university students to find possible causes of bruxism and to detail preventive measures. This study aims to compared the OHRQoL, perceived stress scale (PSS) and Pittsburgh sleep index (PSI) in individuals with and without awake and sleep bruxism in Turkish university students. Moreover, it aims to identify the correlation between PSS, PSI and OHIP-14 scores both the presence of the awake and sleep bruxism. The null hypothesis investigated was that stress levels, sleep quality, and OHRQoL would not present with significantly different outcomes in terms of bruxism.

\section{Materials and Methods}

Four different questionnaires [Self-reported bruxism, PSS, Pittsburgh sleep quality index (PSQI) and OHIP-14] were distributed to volunteer university students randomly selected from various provinces from Turkey. Participants were asked to complete the anonymous questionnaires independently at home, and were encouraged to contact the authors for further assistance when needed. In the study, a survey was collected from 317 dental students. As a result of the survey; 7 (2.2\%) students with systemic diseases were excluded from the study. The study was conducted with 310 students of all ages, male or female. All subjects $(n=310)$ who agreed to participate in the study answered the completed questionnaires within 3 days. A prior power analysis was performed and it was found that 310 samples produces a two-sided $95 \%$ confidence interval with a width equal to 0.220 when the sample correlation is 0.050 . Ethics approval was provided by İstanbul Medipol University Ethics Committee (10840098-604.01.01-E.15516, May 2020). This research adhered to the principles of the Declaration of Helsinki.

\section{Self-reported Bruxism}

The questions used in the present study to evaluate selfreported awake and sleep bruxism were constructed according to the recommendations of Pintado et al. (21) and Lavigne et al. (22) The diagnosis of awake bruxism depended solely on the respondent's awareness ("Have you ever been aware of clenching or grinding your teeth during wakefulness in the past 6 months?" yes/no). Subjects were defined as suffering from awake bruxism if they responded affirmatively to this question. Sleep bruxism was evaluated by a questionnaire based on the diagnostic criteria of the American Academy of Sleep Medicine (2005) (2). Turkish version of self-reported bruxism is not available in the literature; the authors have translated it into Turkish. The questionnaire refers to events during the past 6 months. Respondents were scored as suffering from active sleep bruxism if their answer was positive to question 1 and/or question 2, in addition to at least one positive answer to a symptom listed in question 3 (6).

\section{PSS}

The level of emotional stress was measured by using the PSS, developed by Cohen et al. (23). This questionnaire consists of 14 items and examines stressful feelings and thoughts which the respondent experienced during the past month. The respondent is asked to rate with what frequency he/she felt/thought them on a scale of four ranging from "never" to "very often", with a resulting total score ranging between 0 and 56 (a higher score indicating a higher level of emotional stress). This study used the validated version for Turkish, which showed good psychometrics (intraclass coefficient $=0.87$ and Cronbach's alpha $=0.84)(24)$.

\section{PSQI}

The PSQI includes seven components; subjective sleep quality, sleep latency, sleep duration, sleep efficiency, sleep disturbance, use of sleep medications, and daytime dysfunction (25). The Turkish-language version of the PSQI was used in the present study (26). The score for each subgroup ranges from 0 to 3 . 
The sum of these scores yields one global score of subjective sleep quality (range: $0-21$ ). The sleep quality of those with a total score of $\leq 5$ is considered "good" and those $>5$ is "poor".

\section{OHIP-14}

This self-report questionnaire consists of 14 questions divided into seven domains: functional limitation, physical pain, psychological discomfort, physical disability, psychological disability, social disability, and handicap. The items are rated on a 5-point scale, ranging from 0 (never) to 4 (always), and the final score is the sum of all individual items. Accordingly, the OHIP-14 scores range from 0 to 56 , where the higher scores indicated poor quality of life related to oral health. This study used the validated version for Turkish, which found reliable (Cronbach alpha: 0.74$)$, repeatable $(r=0.932)$, valid and intelligible (96.2\%) (27).

\section{Statistical Analysis}

SPPS 25 (IBM Corp. Released 2017. IBM SPSS Statistics for Windows, Version 25.0. Armonk, NY: IBM Corp.) statistical package program was used to evaluate the data. Descriptive statistics (mean, standard deviation, median value, minimum, maximum, number and percentile) were given for categorical and continuous variables in the study. In addition, the homogeneity of variances, which is one of the prerequisites of parametric tests, was checked with Levene test. Normality assumption was examined with Shapiro-Wilks test. Differences between two groups were evaluated by Student's t-test in case parametric test met the prerequisites; if it was not provided, Mann-Whitney $U$ test was used for comparison of three or more groups. One-Way Analysis of Variance for three or more group comparisons and Tukey HSD test from multiple comparison tests; when not provided, Kruskal-Wallis and Bonferroni-Dunn test from multiple comparison tests were used. The relationship of two continuous variables was evaluated with Pearson Correlation Coefficient and Spearman Correlation Coefficient if the parametric test did not meet the prerequisites. Relationships of categorical variables were analyzed using Fisher's Exact test and chi-square test. In cases where expected frequencies are less than 20\%, an evaluation has been made with Monte Carlo Simulation Method to include these frequencies in the analysis. A level of $\mathrm{p}<0.05$ and $\mathrm{p}<0.01$ was considered statistically significant.

\section{Results}

Table 1 displays demographic characteristics of the students. Participant distribution according to schools displayed $56.8 \%$ study in the department of dentistry and $43.2 \%$ of them study in other departments. Statistical results revealed no difference among the scales, according to the department of the students (OHIP $p=0.086$, PSS $p=0.088$, PSQI $p=0.642 ; p>0.05$ ). The age range of $83.2 \%$ of the participants was $18-25$. Evaluation of the scales by age groups revealed that OHIP-14 scale shows a significant difference according to the ages of the students $(p=0.019, p<0.05)$. There is no significant difference between participants $\leq 18$ and between the ages of $18-25$, it is seen that the scores of students $\geq 25$ are significantly higher than the other age groups. PSS and PSI scores do not differ according to the age groups of the students $(p>0.05)$. Comparison of scales according to marital status revealed no significance (OHIP $p=0.555$, PSS $p=0.482$, PSQI $p=0.388 ; p>0.05)$. The PSI score was found significantly higher in smoking participants $(p=0.001$, $\mathrm{p}<0.05$ ) (Table 2). $68.7 \%$ of the students participating in the study are women and $31.3 \%$ are men. Gender relationship of scales reveal that OHIP-14 and PSS scales are higher in female students than males (OHIP $p=0.001$, PSS $p=0.015 ; p<0.05$ ). PSI scores do not differ among genders $(p=0.129, p>0.05)$ (Table 3).

Self-reported awake bruxism is $29 \%$ and self-reported sleep bruxism is $42.3 \%$. Both awake bruxism and sleep bruxism were reported more frequently by women than by men: $5.2 \%$ vs $3.9 \%$ for awake bruxism and $18.6 \%$ vs $13.9 \%$ for sleep bruxism. Table 4 reveals that OHIP-14 scale has significant difference according to the status of self-reported awake bruxism. Here is a statistically significant difference in the physical pain, psychological discomfort, psychological disability and social disability scales, which are the sub-scales of OHIP-14 ( $p=0.040, p=0.001, p=0.001, p=0.027 ; p<0.05)$. PSI scores reveal statistically significant difference according

\begin{tabular}{|c|c|c|c|}
\hline & & $\mathbf{n}$ & $(\%)$ \\
\hline \multirow{3}{*}{ Department } & Dentistry & 176 & 56.8 \\
\hline & Other & 134 & 43.2 \\
\hline & Total & 310 & 100.0 \\
\hline \multirow{4}{*}{ Age } & $<18$ & 2 & 0.6 \\
\hline & $18-25$ & 258 & 83.2 \\
\hline & $>25$ & 50 & 16.1 \\
\hline & Total & 310 & 100.0 \\
\hline \multirow{3}{*}{ Gender } & Female & 213 & 68.7 \\
\hline & Male & 97 & 31.3 \\
\hline & Total & 310 & 100.0 \\
\hline \multirow{3}{*}{ Marital status } & Single & 293 & 94.5 \\
\hline & Couple & 16 & 5.2 \\
\hline & Total & 309 & 99.7 \\
\hline \multirow{4}{*}{ Cigarette } & No & 213 & 68.7 \\
\hline & Yes & 61 & 19.7 \\
\hline & Not now & 36 & 11.6 \\
\hline & Total & 310 & 100.0 \\
\hline \multirow{4}{*}{ Alcohol } & No & 195 & 62.9 \\
\hline & Yes & 101 & 32.6 \\
\hline & Not now & 14 & 4.5 \\
\hline & Total & 310 & 100.0 \\
\hline \multirow{3}{*}{$\begin{array}{l}\text { Self-reported awake } \\
\text { bruxism }\end{array}$} & No & 220 & 71.0 \\
\hline & Yes & 90 & 29.0 \\
\hline & Total & 310 & 100.0 \\
\hline \multirow{3}{*}{ Self-reported sleep bruxism } & No & 179 & 57.7 \\
\hline & Yes & 131 & 42.3 \\
\hline & Total & 310 & 100.0 \\
\hline
\end{tabular}


to self-reported awake bruxism status. In addition, there is a statistically significant difference in the sub-scales of the PSI, subjective sleep quality, sleep disorder, and use of sleep medicine $(p=0.021, p=0.004, p=0.014 ; p<0.05)$.

Table 5 reveals, the OHIP-14 scale shows a statistically significant difference according to the self-reported sleep bruxism status. There is also statistically significant difference in OHIP-14 subscales of physical pain, psychological discomfort, physical disability, psychological disability, social disability and handikap ( $p=0.001, p=0.001, p=0.001, p=0.010, p=0.007$, $\mathrm{p}=0.015 ; \mathrm{p}<0.05)$. The PSS reveals statistically significant difference according to self-reported sleep bruxism status $(p=0.025 ; p<0.05)$. PSI shows statistically significant difference according to self-reported sleep bruxism status and significant difference in the sub-scales of PSI, subjective sleep quality, sleep duration, sleep disorders, use of sleeping drugs, and daytime dysfunction $(p=0.009, p=0.005, p=0.001, p=0.018$, $\mathrm{p}=0.001 ; \mathrm{p}<0.05)$.

As shown in Table 6, positive correlation of $23.5 \%$ between PSS and OHIP-14 and 24.6\% between PSI and PSS in students with

\begin{tabular}{|c|c|c|c|c|c|c|}
\hline & Scale & Department & $\begin{array}{l}\text { Scale points } \\
(\bar{x} \pm S D)\end{array}$ & Test & $p$ & $\eta^{2}$ \\
\hline \multirow{6}{*}{ Department } & \multirow[t]{2}{*}{ OHIP-14 } & Dentistry & $11.31 \pm 7.79$ & \multirow[t]{2}{*}{-1.717} & \multirow[t]{2}{*}{0.086} & \multirow[t]{2}{*}{0.69} \\
\hline & & Other & $14.22 \pm 9.83$ & & & \\
\hline & \multirow[t]{2}{*}{ PSS } & Dentistry & $30.61 \pm 5.69$ & \multirow[t]{2}{*}{-1.705} & \multirow[t]{2}{*}{0.088} & \multirow[t]{2}{*}{0.72} \\
\hline & & Other & $30.81 \pm 7.30$ & & & \\
\hline & \multirow[t]{2}{*}{ PSI } & Dentistry & $7.32 \pm 2.35$ & \multirow[t]{2}{*}{-0.464} & \multirow[t]{2}{*}{0.642} & \multirow[t]{2}{*}{0.73} \\
\hline & & Other & $6.72 \pm 2.23$ & & & \\
\hline \multirow{9}{*}{ Age } & \multirow[t]{3}{*}{ OHIP-14 } & $<18$ & $4.50 \pm 0.7 a$ & \multirow[t]{3}{*}{7.931} & \multirow[t]{3}{*}{$0.019^{\psi *}$} & \multirow[t]{3}{*}{0.76} \\
\hline & & $18-25$ & $12.01 \pm 8.41^{\mathrm{a}}$ & & & \\
\hline & & $>25$ & $15.76 \pm 10.33^{b}$ & & & \\
\hline & \multirow[t]{3}{*}{ PSS } & $<18$ & $31.00 \pm 9.90$ & \multirow[t]{3}{*}{5.104} & \multirow[t]{3}{*}{0.078} & \multirow[t]{3}{*}{0.71} \\
\hline & & $18-25$ & $30.35 \pm 6.51$ & & & \\
\hline & & $>25$ & $32.46 \pm 5.70$ & & & \\
\hline & \multirow[t]{3}{*}{ PSI } & $<18$ & $4.00 \pm 0.00$ & \multirow[t]{3}{*}{3.789} & \multirow[t]{3}{*}{0.150} & \multirow[t]{3}{*}{0.47} \\
\hline & & $18-25$ & $7.09 \pm 2.36$ & & & \\
\hline & & $>25$ & $7.06 \pm 2.03$ & & & \\
\hline \multirow{9}{*}{ Cigarette } & \multirow[t]{3}{*}{ OHIP-14 } & No & $12.04 \pm 8.48$ & \multirow[t]{3}{*}{3.577} & 0.167 & 0.69 \\
\hline & & Yes & $12.92 \pm 9.22$ & & & \\
\hline & & Not now & $15.11 \pm 9.96$ & & & \\
\hline & PSS & No & $30.84 \pm 6.23$ & 0.467 & 0.792 & 0.43 \\
\hline & & Yes & $30.33 \pm 6.19$ & & & \\
\hline & & Not now & $30.50 \pm 7.96$ & & & \\
\hline & PSI & No & $6.73 \pm 2.31^{\mathrm{a}}$ & 18.041 & $0.001^{\psi * *}$ & 0.79 \\
\hline & & Yes & $8.07 \pm 2.25^{\mathrm{b}}$ & & & \\
\hline & & Not now & $7.31 \pm 1.91^{\mathrm{ab}}$ & & & \\
\hline & OHIP-14 & No & $12.55 \pm 9.07$ & 5.033 & 0.081 & 0.66 \\
\hline & & Yes & $11.81 \pm 7.76$ & & & \\
\hline Alcohol & & Not now & $18.29 \pm 11.16$ & & & \\
\hline & PSS & No & $30.03 \pm 7.04^{\mathrm{a}}$ & 6.460 & $0.040^{\psi *}$ & 0.78 \\
\hline & & Yes & $31.86 \pm 5.28^{a}$ & & & \\
\hline & & Not now & $31.57 \pm 3.18^{\mathrm{ab}}$ & & & \\
\hline & PSI & No & $6.84 \pm 2.33^{\mathrm{a}}$ & 11.840 & $0.003^{\psi * *}$ & 0.78 \\
\hline & & Yes & $7.62 \pm 2.23^{b}$ & & & \\
\hline & & Not now & $6.14 \pm 1.92^{\mathrm{a}}$ & & & \\
\hline
\end{tabular}




\begin{tabular}{|c|c|c|c|c|c|}
\hline Scale & Gender & $\begin{array}{l}\text { Scale points } \\
(\bar{x} \pm S D)\end{array}$ & Test & $p$ & $\eta^{2}$ \\
\hline \multirow{2}{*}{ OHIP-14 } & Woman & $13.67 \pm 8.70$ & \multirow{2}{*}{-3.865} & \multirow{2}{*}{$0.001^{* * *}$} & \\
\hline & Man & $10.15 \pm 8.69$ & & & 0.81 \\
\hline \multirow{2}{*}{ PSS } & Woman & $31.22 \pm 6.49$ & \multirow{2}{*}{-2.424} & \multirow{2}{*}{$0.015^{\psi *}$} & \multirow{2}{*}{0.83} \\
\hline & Man & $29.55 \pm 6.15$ & & & \\
\hline \multirow{2}{*}{ PSI } & Woman & $7.17 \pm 2.18$ & \multirow{2}{*}{-1.517} & \multirow{2}{*}{0.129} & \multirow{2}{*}{0.22} \\
\hline & Man & $6.81 \pm 2.58$ & & & \\
\hline
\end{tabular}

self-reported awake bruxism are displayed $(p=0.235, p=0.246$; $\mathrm{p}<0.05)$. There is statistically significant positive correlation of 23.1\% between PSS and OHIP-14 and 29.6\% between PSI and PSS in students with self-reported sleep bruxism $(p=0.231$, $\mathrm{p}=0.296 ; \mathrm{p}<0.05)$.

\section{Discussion}

Stress plays a role in sleep and awake bruxism. Past studies support, participants who reported bruxism claimed to have higher levels of emotional stress than those without bruxism $(3,28)$. As a limitation of this study, the use of self-reported bruxism scale, which is an assessment tool based only on the reports of individuals, can be evaluated in the diagnosis of

\begin{tabular}{|c|c|c|c|c|c|c|}
\hline \multicolumn{2}{|l|}{ Scale } & Self-reported awake bruxism & Scale points $(\bar{x} \pm S D)$ & Test & $\mathbf{p}$ & $\eta^{2}$ \\
\hline \multirow{16}{*}{ OHIP-14 } & \multirow{2}{*}{ Total test } & No & $11.50 \pm 8.87$ & \multirow{2}{*}{-4.176} & \multirow{2}{*}{$0.001^{\psi * *}$} & \multirow{2}{*}{0.83} \\
\hline & & Yes & $15.17 \pm 8.24$ & & & \\
\hline & \multirow{2}{*}{ Functional limitation } & No & $0.54 \pm 1.17$ & \multirow{2}{*}{-1.885} & \multirow{2}{*}{0.059} & \multirow{2}{*}{0.71} \\
\hline & & Yes & $0.84 \pm 1.59$ & & & \\
\hline & \multirow{2}{*}{ Physical pain } & No & $2.50 \pm 2.02$ & \multirow{2}{*}{-2.051} & \multirow{2}{*}{$0.040^{\psi *}$} & \multirow{2}{*}{0.84} \\
\hline & & Yes & $2.99 \pm 1.97$ & & & \\
\hline & \multirow{2}{*}{ Psychological discomfort } & No & $3.62 \pm 1.78$ & \multirow{2}{*}{-5.409} & \multirow{2}{*}{$0.001^{\psi * \star}$} & \multirow{2}{*}{0.88} \\
\hline & & Yes & $4.92 \pm 1.71$ & & & \\
\hline & \multirow{2}{*}{ Physical disability } & No & $1.28 \pm 1.68$ & \multirow{2}{*}{-1.504} & \multirow{2}{*}{0.133} & \multirow{2}{*}{0.44} \\
\hline & & Yes & $1.53 \pm 1.73$ & & & \\
\hline & \multirow{2}{*}{ Psychological disability } & No & $1.45 \pm 1.72$ & \multirow{2}{*}{-3.387} & \multirow{2}{*}{$0.001^{\psi * *}$} & \multirow{2}{*}{0.88} \\
\hline & & Yes & $2.11 \pm 1.84$ & & & \\
\hline & \multirow{2}{*}{ Social disability } & No & $1.12 \pm 1.62$ & \multirow{2}{*}{-2.205} & 00270 : & 000 \\
\hline & & Yes & $1.63 \pm 1.99$ & & $0.021^{* *}$ & 0.89 \\
\hline & Handiran & No & $0.99 \pm 1.45$ & 1616 & 0100 & 011 \\
\hline & Handicap & Yes & $1.13 \pm 1.33$ & -1.646 & 0.100 & 0.14 \\
\hline DSC & Total toct 100 & No & $30.17 \pm 6.83$ & 1021 & 0067 & 012 \\
\hline PSS & Iotal test & Yes & $31.99 \pm 5.12$ & $|-1.83|$ & $0.06 \%$ & 0.42 \\
\hline & Total toct & No & $6.85 \pm 2.36$ & 2602 & $0007 * * *$ & 011 \\
\hline & Iotal test & Yes & $7.58 \pm 2.12$ & -2.682 & $0.00 / 4 \pi x$ & 0.44 \\
\hline & cubiotive bron & No & $1.56 \pm 0.69$ & 2210 & 0021 * & $0<0$ \\
\hline & subjective sieep quality & Yes & $1.37 \pm 0.68$ & -2.310 & $0.0211^{4 n}$ & 0.69 \\
\hline & Clono latongy & No & $1.35 \pm 1.08$ & 1052 & 0202 & 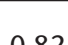 \\
\hline & Sleep Iatency & Yes & $1.50 \pm 1.02$ & -1.033 & 0.292 & 0.82 \\
\hline & Sleon duration & No & $0.88 \pm 1.06$ & 1836 & 0066 & $066-10$ \\
\hline DGi & Sleep duration & Yes & $1.12 \pm 1.11$ & -1.836 & 0.066 & 0.66 \\
\hline PI & Hahitual slone ffiras & No & $0.11 \pm 0.49$ & 0302 & 0604 & 011 \\
\hline & Habıtual sleep effıcacy & Yes & $0.07 \pm 0.33$ & -0.393 & 0.694 & 0.44 \\
\hline & & No & $1.48 \pm 0.65$ & & & \\
\hline & Sleep disturbances & Yes & $1.72 \pm 0.65$ & -2.849 & $0.004^{\psi * \star}$ & 0.64 \\
\hline & Clonning modisation & No & $0.06 \pm 0.32$ & & & \\
\hline & Sleeping medications & Yes & $0.19 \pm 0.54$ & -2.470 & $0.014^{\psi *}$ & 0.34 \\
\hline & Dautime ducfunction & No & $1.40 \pm 0.99$ & 1612 & & \\
\hline & Daytıme dystunction & Yes & $1.61 \pm 0.93$ & -1.612 & 0.107 & 0.47 \\
\hline
\end{tabular}




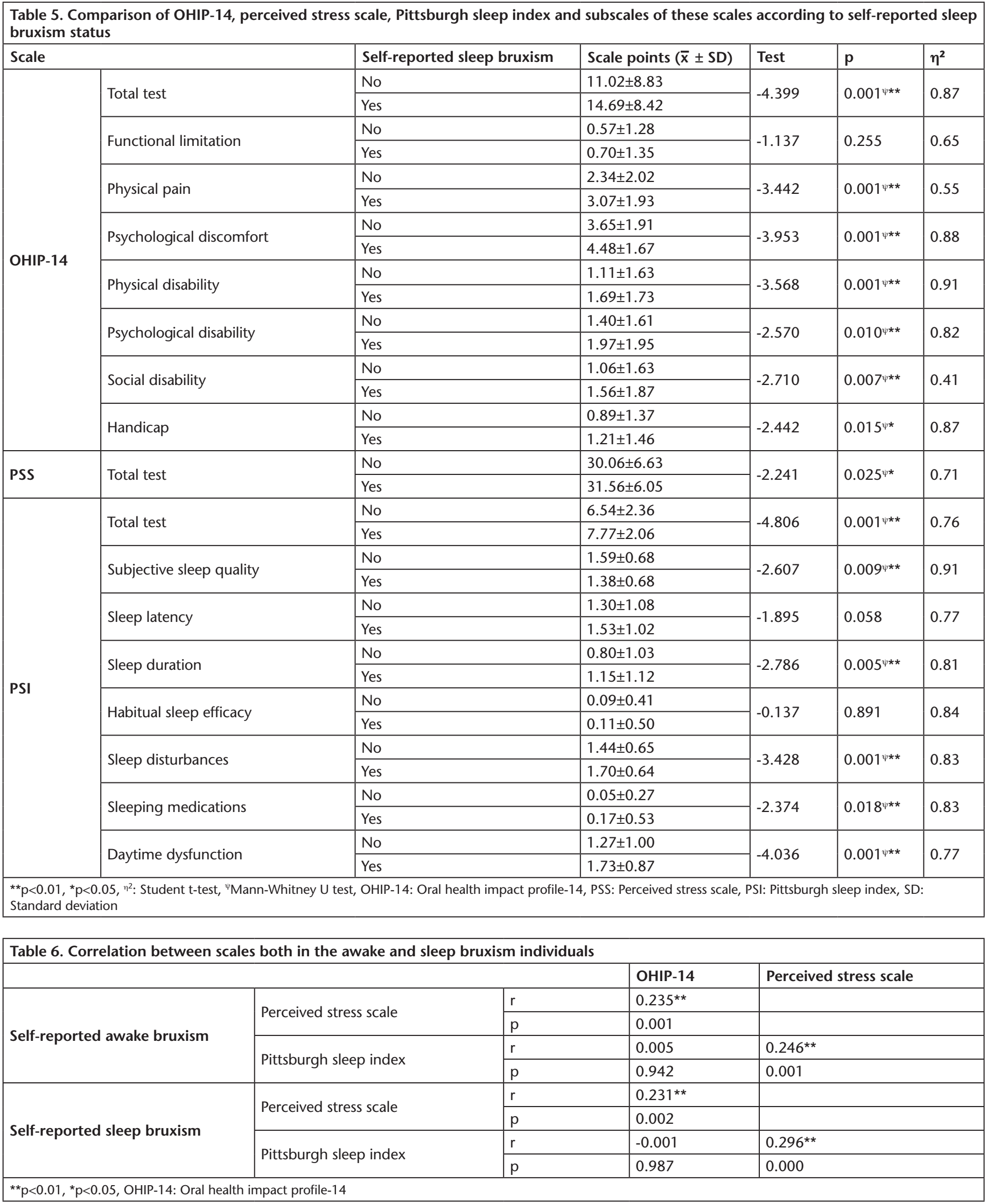


bruxism. However, similar to studies conducted with clinical diagnoses, the stress levels of students with self-reported sleep bruxism are higher than those without bruxism (28). Another limitation of this study is that the prevalence of bruxism in our sample group was higher than in the general population. The reason for this limitation can be considered as the previous limitation itself, that is, determining the diagnosis of bruxism with a single assessment tool.

Another issue discussed is that emotional stress impairs sleep quality (21), its effect on the transition between deep sleep and lighter sleep, and bruxism occurs as a result of these microstimulations $(6,29)$. Although sleep quality values are close to each other between individuals with and without awake or sleep bruxism, a second complaint accompanying individuals with particularly high stress levels is poor sleep quality (29).

In general, the presence of high stress levels of students appears to be consistent with the previous literature (30). Therefore, the first null hypothesis could be rejected. Recent literature on correlation of stress and bruxism reveals that stress induces neuromuscular changes in the mouth and jaw in university students, affecting the overall prevalence of temporomandibular disorders (31). In terms of studies involving university setting, an association between bruxism and stress has been demonstrated (32) and the literature reports an increase in the self-reported incidence of nocturnal bruxism among university students over the past decade (20).

The existence of gender effect on stress for college students is also consistent with our study: most studies reported higher stress for female students $(33,34)$. Previous studies have shown that bruxism is also prevalent among females in the general population (35) and students have also shown a higher prevalence among females, as we confirmed in our study $(36,37)$. Also, studies related to stress levels and gender (38) reveal that women report that they perceive higher levels of stress than men (6).

Age-related OHRQOL in the literature shows more negative outcomes with increasing age $(9,17)$. The findings in our study also support worse OHRQoL in individuals over 25 years of age. Assessment of sleep quality in the bruksoman population may help to better characterize these patients and, moreover, addressing sleep disturbances may reference other therapeutic approaches to improve sleep quality. Mean PSQI scores ranged from 6.08 (24) to 10.8 (39) in recent studies suggesting poor sleep quality in patients with sleep bruxism. Poor sleep quality of university students with both drowsy and awake bruxism in our study supports the literature (40). Considering that bruxers have high sensitivity to psychological stress (41) and psychophysiological insomnia is characterized by response to stress (42), the loss of sleep quality among bruxers in our study may be explained.

Data of self-reported college students with bruxism present worse OHRQoL and sleep quality. The total scores of OHIP14 reveal that the bruxers perceived their OHRQoL more negatively than controls $(19,43)$. In this study, we adopted the OHIP-14, the most widely used questionnaire to access
OHRQoL (44). When the OHIP is evaluated in seven areas (functional limitations, physical pain, psychological discomfort, physical disability, psychological disability, social disability, and disability), the high scores of all subscales, thus poor OHRQoL, indicate those with self-reported bruxism. A study in orthodontic treatment patients also supports the relationship between bruxism and poor OHRQoL; those with bruxism have higher symptoms of anxiety and depression and weaker OHRQoL (45).

Statistically higher scores were found in the areas of psychological discomfort (confident and nervous), psychological inadequacy (difficult to relax and shame) and physical pain (pain and discomfort) among participants, compared to other groups; suggesting greater tendency for psychosocial, emotional, and pain disorders. It was stated that psychological factors may play a role in the estimated etiology of bruxism (46), and results associated with stress also supported this situation (14). Moreover, bruxers had a high consumption of tobacco and alcohol, which is supported by the current literature. BertazzoSilveira et al. (47) show in their study that the probability for bruxism increases 2 times for alcohol drinkers and more than 2 times for smokers.

\section{Conclusion}

Self-reported awake or sleep bruxism is associated with higher stress levels, sleep disturbances, and weaker OHRQoL in university students. Other factors (alcohol, caffeine and tobacco use) that are consistently associated with bruxism that may affect OHRQoL should also be investigated.

\section{Ethics}

Ethics Committee Approval: Ethics approval was provided by İstanbul Medipol University Ethics Committee (10840098604.01.01-E.15516, May 2020). This research adhered to the principles of the Declaration of Helsinki.

Informed Consent: Informed consent form was obtained from all participants included in our study.

Peer-review: Externally peer-reviewed.

\section{Authorship Contributions}

Concept: H.E.Ö., Design: S.G., H.E.Ö., K.C.A., Data Collection or Processing: H.E.Ö., S.G., K.C.A., Analysis or Interpretation: H.E.Ö., S.G., K.C.A., Literature Search: H.E.Ö., S.G., K.C.A., Writing: H.E.Ö.

Conflict of Interest: No conflict of interest was declared by the authors.

Financial Disclosure: The authors declared that this study received no financial support.

\section{References}

1. De Leeuw R. Orofacial Pain Guidelines for Assessment, Diagnosis, and Management, 4th ed. Chicago, Berlin, London, Tokyo, Sao Paulo, Prague, and Warsaw: Quintessence Publishing, 2008;129-204.

2. American Academy of Sleep Medicine (AASM). The International Classification of Sleep Disorders Revised: Diagnostic and Coding Manual (ICSD), 2nd ed. Westchester, IL: American Academy of Sleep Medicine, 2005; 13-24. 
3. Lobbezoo F, Naeije M. Bruxism is mainly regulated centrally, not peripherally. J Oral Rehabil 2001;28:1085-91.

4. Ohayon MM, Li KK, Guilleminault C. Risk factors for sleep bruxism in the general population. Chest 2001;119:53-61.

5. Lavigne G], Khoury S, Abe S, Yamaguchi T, Raphael K. Bruxism physiology and pathology: an overview for clinicians. J Oral Rehabil 2008;35:476-94.

6. Winocur E, Uziel N, Lisha T, Goldsmith C, Eli I. Self-reported Bruxism associations with perceived stress, motivation for control, dental anxiety and gagging. J Oral Rehabil 2011;38:3-11.

7. Booij SH, Snippe E, Jeronimus BF, Wichers M, Wigman JTW. Affective reactivity to daily life stress: relationship to posi- tive psychotic and depressive symptoms in a general population sample. J Affect Disord 2017;225:474-81.

8. Câmara-Souza MB, de Figueredo OMC, Rodrigues Garcia RCM. Association of sleep bruxism with oral health-related quality of life and sleep quality. Clin Oral Investig 2019;23:245-51.

9. Su N, Liu Y, Yang X, Shen J, Wang H. Association of malocclusion, self-reported bruxism and chewing-side preference with oral healthrelated quality of life in patients with temporomandibular joint osteoarthritis. Int Dent J 2018;68:97-104.

10. Allen PF. Assessment of oral health related quality of life. Health Qual Life Outcomes 2003;1:40.

11. Sischo L, Broder HL. Oral health-related quality of life: What, why, how, and future implications. J Dent Res 2011;90:1264-70.

12. Tay KJ, Ujin YA, Allen PF. Impact of Sleep Bruxism on Oral HealthRelated Quality of Life. Int J Prosthodont 2020;33:285-91.

13. Ahlberg J, Lobbezoo F, Ahlberg K, Manfredini D, Hublin C, Sinisalo J, Könönen M, Savolainen A. Self-reported bruxism mirrors anxiety and stress in adults. Med Oral Patol Oral Cir Bucal 2013;18:7-11.

14. Carra MC, Huynh N, Lavigne G. Sleep bruxism: a comprehensive overview for the dental clinician interested in sleep medicine. Dent Clin North Am 2012;56:387-413.

15. Smith MT, Perlis ML, Smith MS, Giles DE, Carmody TP. Sleep quality and presleep arousal in chronic pain. J Behav Med 2000;23:1-13.

16. Manfredini D, Arreghini A, Lombardo L, Visentin A, Cerea S, Castroflorio T, Siciliani G. Assessment ofanxiety and coping features in bruxers: a portable electromyographic and electrocardiographic study. J Oral Facial Pain Headache 2016;30:249-54.

17. Câmara-Souza MB, de Figueredo OMC, Rodrigues Garcia RCM. Masticatory function and oral stereognosis in bruxers. Cranio 2019;37:285-9.

18. Bader G, Lavigne G. Sleep bruxism; an overview of an oromandibular sleep movement disorder: review article. Sleep Med Rev 2000;4:27-43.

19. Granada S, Hicks RA. Changes in self-reported incidence of nocturnal bruxism in college students: 1966-2002. Percept Mot Skills 2003;97:777-8.

20. Newbury-Birch D, Lowry RJ, Kamali F. The changing patterns of drinking, illicit drug use, stress, anxiety and depression in dental students in a UK dental school: a longitudinal study. $\mathrm{Br}$ Dent J 2002;192:646-9.

21. Pintado MR, Anderson GC, DeLong R, Douglas WH. Variation in tooth wear in young adults over a two-year period. J Prosthet Dent 1997;77:313-20.

22. Lavigne GJ, Rompré PH, Montplaisir JY. Sleep bruxism: validity of clinical research diagnostic criteria in a controlled polysomnographic study. J Dent Res 1996;75:546-52.

23. Cohen S, Kamarck T, Mermelstein R. A global measure of perceived stress. J Health Socl Behav 1983;24:385-96.
24. Eskin M, Harlak H, Demirkıran F, Dereboy C. The Adaptation of the Perceived Stress Scale Into Turkish: A Reliability and Validity Analysis. New Symposium Journal 2013;51:132-40.

25. Lei J, Fu J, Yap AU, Fu KY. Temporomandibular disorders symptoms in Asian adolescents and their association with sleep quality and psychological distress. Cranio 2016;34:242-9.

26. Ağargün MY, Kara $H$, Anlar Ö. The validity and reliability of the Pittsburgh sleep quality index. Turk J Psychiatry 1996;7:107-15.

27. Başol ME, Karaağaçlıoğlu L, Yılmaz B. Developing a Turkish Oral Health Impact Profile-OHIP-14-TR. Turkiye Klinikleri J Dental Sci 2014;20:85-92.

28. Fischer WF, O'toole ET. Personality characteristics of chronic bruxers. Behav Med 1993; 19:82-6.

29. Manfredini D, Ahlberg J, Winocur E, Lobbezoo F. Management of sleep bruxism in adults: a qualitative systematic literature review. J Oral Rehabil 2015;42:862-74.

30. Hinton JW, Rotheiler E. Stress, health and performance in university students. Z Gesamte Hyg 1990;36:634-5.

31. Akhter R, Morita M, Esaki M, Nakamura K, Kanehira T. Development of temporomandibular disorder symptoms: a 3-year cohort study of university students. J Oral Rehabil 2011;38:395-403.

32. Westrup DA, Keller SR, Nellis TA, Hicks RA. Arousability and bruxism in male and female college students. Percept Mot Skills 1992;75:796-8.

33. Mikolajczyk RT, El Ansari W, Maxwell AE. Food consumption frequency and perceived stress and depressive symptoms among students in three European countries. Nutr J 2009;8:31.

34. Shah M, Hasan S, Malik S, Sreeramareddy CT. Perceived stress, sources and severity of stress among medical undergraduates in a Pakistani medical school. BMC Med Educ 2010;10:2.

35. Shetty S, Pitti V, Satish Babu CL, Surendra Kumar GP, Deepthi BC. Bruxism: a literature review. J Indian Prosthodont Soc 2010;10:141-8.

36. Mizutani S, Ekuni D, Tomofuji T, Azuma T, Irie K, Machida T, Yoneda T, Iwasaki Y, Morita M. Factors related to the formation of buccal mucosa ridging in university students. Acta Odontol Scand 2014;72:58-63.

37. Itani O, Kaneita Y, Ikeda M, Kondo S, Yamamoto R, Osaki Y, Kanda H, Suzuki K, Higuchi S, Ohida T. Disorders of arousal and sleep-related bruxism among Japanese adolescents: a nationwide representative survey. Sleep Med 2013;14:532-41.

38. Farabaugh AH, Mischoulon D, Fava M, Green C, Guyker W, Alpert J. The potential relationship between levels of perceived stress and subtypes of major depressive disorder (MDD). Acta Psychiatr Scand 2004; 110:465-70.

39. Saletu A, Parapatics S, Saletu B, Anderer P, Prause W. On the pharmacotherapy of sleep bruxism: placebo- controlled polysomnographic and psychometric studies with clonazepam. Neuropsychobiology 2005;51:214-25.

40. Rener-Sitar K, John MT, Pusalavidyasagar SS, Bandyopadhyay D, Schiffman EL. Sleep quality in temporomandibular disorder cases. Sleep Med 2016;25:105-12.

41. Abekura H, Tsuboi M, Okura T, Kagawa K, Sadamori S, Akagawa Y. Association between sleep bruxism and stress sensitivity in an experimental psychological stress task. Biomed Res 2011;32:395-9

42. Bonnet MH, Arand DL. Hyperarousal and insomnia: state of the science. Sleep Med Rev 2010;14:9-15.

43. Ujin Yap A, Cao Y, Zhang MJ, Lei J, Fu KY. Age-related differences in diagnostic categories, psychological states and oral health-related quality of life of adult temporomandibular disorder patients. J Oral Rehabil 2021;48:361-8.

44. John MT, Reissmann DR, Feuerstahler L, Waller N, Baba K, Larsson $P$, Celebić A, Szabo G, Rener-Sitar K. Exploratory factor analysis of the Oral Health Impact Profile. J Oral Rehabil 2014;41:635-43. 
Ekşi Özsoy et al.

Stress Levels, Sleep Quality, and Bruxism

45. Machado NAG, Costa YM, Quevedo HM, Stuginski-Barbosa J, Valle CM, Bonjardim LR, Garib DG, Conti PCR. The association of selfreported awake bruxism with anxiety, depression, pain threshold at pressure, pain vigilance, and quality of life in patients undergoing orthodontic treatment. J Appl Oral Sci 2020;28:e20190407.

46. Manfredini D, Lobbezoo F. Role of psychosocial factors in the etiology of bruxism. J Orofac Pain 2009;23:153-66.
47. Bertazzo-Silveira E, Kruger CM, Porto De Toledo I, Porporatti AL, Dick B, Flores-Mir C, De Luca Canto G. Association between sleep bruxism and alcohol, caffeine, tobacco, and drug abuse: a systematic review. J Am Dent Assoc 2016;147:859-66. 